Zeszyty Naukowe Szkoły Głównej Gospodarstwa Wiejskiego w Warszawie Problemy Rolnictwa Światowego tom 17 (XXXII), zeszyt 2, 2017: 136-143

DOI: 10.22630/PRS.2017.17.2.33

Julian T. Krzyżanowski ${ }^{1}$

Szkoła Główna Gospodarstwa Wiejskiego w Warszawie

\title{
Krajowe systemy zapewnienia jakości żywności w wybranych krajach Unii Europejskiej
}

\section{National Systems of Assuring Food Quality in Selected EU Countries}

\begin{abstract}
Synopsis. Celem opracowania jest próba wykazania, że w warunkach polskich możliwe jest zbudowanie jednego narodowego (krajowego) systemu jakości. Jeden system jakości powodowałby lepszą jego rozpoznawalność dla wszystkich uczestników rynku, ułatwiłby szersze uczestnictwo w systemie dla podmiotów krajowych i w przyszłości zagranicznych. Zapobiegał by też chaosowi informacyjnemu. Jeden krajowy system zapewnienia jakości żywności jest powszechny w krajach Unii Europejskich. Przedstawienie zrębów systemu jakości w niektórych państwach UE jest dodatkowym, a właściwie pierwotnym celem artykułu.
\end{abstract}

Słowa kluczowe: systemy jakości, żywność, Polska, Unia Europejska

\begin{abstract}
The aim of this paper is to demonstrate that it is possible in Polish conditions to create one national quality system. One system allows for better recognition for all market stakeholders. It enables broader participation in the system for national and in future foreign entities. Such system also prevents an information chaos. A single system also common in the EU countries. Presentation of the foundations of the system in some EU countries is both the additional and actually a primary objective of this article.
\end{abstract}

Key words: quality systems, food, Poland, European Union

\section{Wprowadzenie}

Wraz z rozwojem rynków i wzrostem ilości powiązań pomiędzy podmiotami zajmującymi się produkcją, przetwórstwem i obrotem artykułami rolno-spożywczymi, rośnie ryzyko pogorszenia jakości żywności. Ponieważ wystąpienie tego zagrożenia może mieć miejsce na każdym etapie łańcucha żywnościowego, niezbędne jest stworzenie systemu w ramach którego wszyscy jego uczestnicy będą spełniali ustanowione wymagania pozwalające zapewnić wyższe parametry jakościowe produktu (Wymagania, 2013).W Unii Europejskiej, już w latach dziewięćdziesiątych ubiegłego wieku wprowadzono europejskie systemy jakości żywności (system Chronionych Nazw Pochodzenia, Chronionych Oznaczeń Geograficznych, Gwarantowanych Tradycyjnych Specjalności oraz Rolnictwo Ekologiczne), które wyróżniają produkty wysokiej jakości i podkreślają region ich pochodzenia oraz tradycyjne metody ich produkcji. Podstawą prawną dla uruchomienia tych systemów były trzy rozporządzenia (Rozporządzenia EEC 1991/1992), a obecnie

${ }^{1}$ dr hab., prof. SGGW, Katedra Ekonomiki Rolnictwa i Międzynarodowych Stosunków Gospodarczych SGGW, ul. Nowoursynowska 166, 02-787 Warszawa, e-mail: julian_krzyzanowski@sggw.pl 
Rozporządzenie Parlamentu Europejskiego i Rady (UE) nr 1151/2012 z dnia 21 listopada 2012 r. w sprawie systemów jakości produktów rolnych i środków spożywczych (Rozporządzenie, 2012).

Są to jednak systemy niszowe, obejmujące np. we Francji ważny sektor wina, ale nie obejmujące rynków podstawowych w rolnictwie większości krajów.

Dlatego też każdy kraj ma prawo do stworzenia także własnych krajowych systemów jakościowych. Ogólne wymogi dla tych systemów zostały sformułowane w Rozporządzeniu Komisji (WE) nr 1974/2006 z dnia 15 grudnia 2006 r. (Rozporządzenie, 2006).

Celem opracowania jest próba wykazania, że w warunkach polskich możliwe jest zbudowanie jednego narodowego (krajowego) systemu jakości. Jeden system jakości powodowałby lepszą jego rozpoznawalność dla wszystkich uczestników rynku, ułatwił by szersze uczestnictwo w systemie dla podmiotów krajowych i w przyszłości zagranicznych. Zapobiegał by też chaosowi informacyjnemu. Jeden krajowy system zapewnienia jakości żywności jest powszechny w krajach Unii Europejskich. Przedstawienie zrębów systemu jakości w niektórych państwach UE jest dodatkowym, a właściwie pierwotnym celem artykułu. Wybór krajów nie jest przypadkowy. Spośród „starych” krajów członkowskich UE, Austria, Niemcy i Francja dysponują najbardziej dojrzałymi systemami zapewnienia żywności (Kondraciuk, 2008). Z „nowych” krajów członkowskich, można to samo powiedzieć o Słowenii. Ustalenia pozwalają wyciągnąc wnioski dla tworzących systemy jakości w naszym kraju.

\section{Austriacki system jakości żywności}

W 1992 r., W Austrii na mocy ustawy utworzono Austriacką Agencję Rynku Rolnego (Agramarkt Austria - AMA), która wypromowała system jakości oparty na znaku „AMAGütesiegel" (Sprawozdanie..., 2016). Znak ten przyznawany jest produktom, które spełniają określone kryteria jakości dotyczące metod produkcji, oraz wymogi określające pochodzenie geograficzne produktów. Ponadto, system zobowiązuje do przestrzegania wymagań dobrostanu zwierząt i higienicznych. Warto podkreślić, że o przyznanie znaku, „AMA-Gütesiegel” mogą wnioskować producenci z innych państw i regionów UE. Znak ten przyznawany jest dla następujących produktów: mięsa surowego, przetworów mięsnych, mleka i przetworów mlecznych, owoców, warzyw i ziemniaków, świeżych jaj. Konstrukcja znaku jakości „AMA-Gütesiegel” opiera się na trzech filarach:

- kontrolowana jakość - normy jakościowe mające zastosowanie do każdego produktu przewyższają wymagania prawne i ich przestrzeganie jest kontrolowane za pomocą obiektywnych metod;

- kontrolowane pochodzenie - identyfikowalne źródło pochodzenia np. oznaczenie słowne i barwy narodowe odnoszą się do źródeł pochodzenia produktu;

- niezależne inspekcje (własna, zewnętrzna i nadzorcy) - kontrole są przeprowadzane na wszystkich etapach produkcji i przetwarzania, aż do momentu gdy towar trafi do sklepu.

Oprócz ciagłych inspekcji własnych, przeprowadzanych przez rolników, regularne kontrole są również przeprowadzane przez niezależnych, wyspecjalizowanych kontrolerów, którzy z kolei podlegają inspekcjom. 
Agencja Agramarkt Austria - AMA odpowiada nie tylko za zarządzanie jakością, ale również za marketing znaku. Są to działania dotyczące marketingu usług, oraz szeroko rozumiana promocja tj. kampanie znaku jakości „AMA-Gütesiegel", kampanie na rzecz konsumpcji, projekty on-line, broszury tematyczne, a także oznakowania w sklepach. Dzięki działaniom Agencji, znak „AMA-Gütesiegel" jest jednym z najbardziej rozpoznawalnych znaków w Austrii i cieszy się dużym zaufaniem zarówno wśród producentów jak i konsumentów. W programie uczestniczy 43 tys. rolników i 700 przetwórców. Rozpoznawalność znaku jest także wysoka (96\%).

\section{System stosowany w Niemczech}

W Niemczech od 1993 roku (Kondraciuk, 2008), istnieje Fundusz Wspierania Sprzedaży Niemieckiego Rolnictwa i Gospodarki Żywnościowej. Jest on instytucją prawa publicznego. Dla wykonywania swoich zadań Fundusz otrzymuje środki z obowiązkowych wpłat poszczególnych branż rolniczych. Jednym z finansowanych działań jest poprawa jakości artykułów żywnościowych wytwarzanych w Niemczech m.in. poprzez budowę i funkcjonowanie systemu jakości żywności „QS - Ihr Prüfsystem für Lebensmittel“" System ten daje gwarancję jakości przy wytwarzaniu produktów rolno-spożywczych w obrębie całego łańcucha, tzn. zapewnia jakość produktu „od pola do stołu”. Podstawą systemu jest przejrzystość wytwarzania danego produktu rolno-spożywczego, a także dokładna dokumentacja oraz kontrole na każdym etapie produkcji. System „QS” wyznacza dla każdego etapu produkcji warunki, jakie muszą być spełnione oraz zapewnia kontrolę spełnienia tychże warunków. Takie rozwiązanie jest korzystne zarówno dla konsumentów, którzy mogą kupić żywność o gwarantowanym pochodzeniu i jakości, jak i dla uczestników poszczególnych etapów wytwarzania produktu. Mogą oni bowiem, skoncentrować się na swoim etapie produkcji, bez konieczności kontrolowania pochodzenia składników do wytwarzanego przez nich produktu.

Nadzór nad systemem sprawuje organizacja „QS Qualität und SicherheitGmbH” („QS Jakość i Bezpieczeństwo Sp. z o.o.”). W jej skład wchodzą przedstawiciele związków i organizacji producentów, przetwórców oraz przedstawiciele CMA („Centrale Marketing Gesellschaft der deutschen Agrarwirtschaft mbH” - Centralna Spółka Marketingowa Niemieckiej Gospodarki Rolnej), organizacja, która prowadzi działania marketingowe finansowane z Funduszu Wspierania Sprzedaży Niemieckiego Rolnictwa i Gospodarki Żywnościowej).Do zadań „QS Qualität und Sicherheit GmbH” należy:

- określanie wytycznych, jakie muszą spełniać produkty ubiegające się o znak jakości „QS",

- koordynowanie kontroli systemu.

Jakość produktu gwarantuje trójstopniowa kontrola produktu prowadzona na każdym etapie wytwarzania. Pierwszym etapem jest kontrola wewnątrzzakładowa przeprowadzana przez samego przedsiębiorcę, skoncentrowana głównie na kontroli dokumentacji. Drugim stopniem jest kontrola zewnętrzna, która przeprowadzana jest $m$. in. przez wyspecjalizowane instytuty. Polega ona na sprawdzaniu czy produkcja odbywa się zgodnie z wytycznymi gwarantującymi jakość, a także jak działa kontrola wewnętrzna. Wyniki każdej kontroli instytuty te obowiązane są przekazywać do „QS Qualität und Sicherheit GmbH”, która nadzoruje cały system i przeprowadza kontrolę na trzecim etapie. Niemiecki system jakości obejmuje: 
- mięso surowe oraz przetwory mięsne,

- świeże owoce i warzywa,

- ziemniaki.

Do systemu mogą przystapić także producenci $\mathrm{z}$ zagranicy. Każdy producent $\mathrm{z}$ obszaru Wspólnoty Europejskiej może otrzymać znak jakości „QS”, o ile spełni on wszystkie wymogi stawiane uczestnikowi danego systemu gwarantowania jakości. Program obejmuje ponad 100 tysięcy podmiotów z różnych branż. Rozpoznawalność znaku wynosi 60 procent.

\section{Francuski system Label Rouge}

Program ten jest programem promocji wysokiej jakości towarów rolno-spożywczych. Godło promocyjne jest własnością francuskiego Ministerstwa Rolnictwa i Rybołówstwa. Zasady zdobywania godła promocyjnego są jednak sprywatyzowane. Specjalne jednostki akredytują jednostki kontrolne, które następnie kontrolują ex-ante i ex-post zgodność deklaracji przedsiębiorców ubiegających się o udział $\mathrm{w}$ programie $\mathrm{z}$ wymaganiami jakościowymi (Kondraciuk, 2008).

Generalnie Label Rouge jest nadawany produktom francuskim. Wyjątkiem od tej reguły jest przyznanie marki Label Rouge łososiowi szkockiemu. Wysokiej jakości łosoś szkocki otrzymał akredytację w ramach programu już w 1992 roku.

Program Label Rouge powstał na mocy ustawy z 1960 roku, Label Rouge gwarantuje najwyższą jakość dla danego typu produktu. Produkt ten powinien wyróżniać się wśród innych podobnych produktów oferowanych na rynku. Dotyczy to warunków produkcji. Różnica $\mathrm{w}$ jakości w odniesieniu do innych dostępnych na rynku produktów powinna być bezpośrednio widoczna dla odbiorcy końcowego, zarówno w odniesieniu do smaku, jak i wizerunku produktu.

We Francji obecnie ponad 400 produktów jest objętych znakiem Label Rouge. Warto dodać że znak Label Rouge jest przyznawany wyłącznie całej sieci produkcyjnej, co jest niełatwe do zastosowania. Sieć produkcyjna składa się z producentów, przetwórców i pośredników zorganizowanych w grupę jakościową. Label Rouge obejmuje dziś całą gamę produktów takich jak ryby i owoce morza, owoce i warzywa, wędliny, produkty mleczne, jaja, dania gotowe, napoje (Kondraciuk, 2008).

\section{System jakości żywności "Wyselekcjonowana Jakość" wdrożony w Słowenii}

Oznaczenie „wyselekcjonowanej jakości" (Sprawozdanie, 2016) ma służyć do znakowania produktów rolnych i środków spożywczych pochodzących z sektora produkcji i przetwórstwa mleka, produkcji i przetwórstwa mięsa, produkcji i przetwórstwa owoców.

W dokumencie dotyczącym „wyselekcjonowanej jakości" (Slovenian, 2015) zostały zawarte zasady, które określają procedurę kwalifikacji do oznaczenia „wyselekcjonowanej jakości", działania komisji ekspertów, sposób oceniania zgodności, warunki, jakie muszą spełnić organizacje prowadzące kontrolę produktów rolnych i środków spożywczych oraz dokonujące ich certyfikacji, a także wzór graficzny znaku „wyselekcjonowana jakość”. Uczestnikami (beneficjentami)systemu mogą być: 
- stowarzyszenie lub grupa producentów bądź przetwórców, bez względu na ich formę prawna, które reprezentują producentów i przetwórców wytwarzających i przetwarzających produkty rolne i środki spożywcze z wyszczególnionych sektorów,

- podmiot prawa publicznego upoważniony zgodnie $\mathrm{z}$ prawem do reprezentowania producentów,

- organizacja reprezentująca, na podstawie uprawnień statutowych, interesy producentów lub przetwórców z wyszczególnionych sektorów.

Procedura włączenia uczestnika do systemu jest następująca:

- złożenie wniosku do Ministerstwa Rolnictwa o zakwalifikowanie do oznaczenia „wyselekcjonowanej jakości",

- publikacja specyfikacji na stronie internetowej ministerstwa rolnictwa,

- decyzja Ministerstwa Rolnictwa o kwalifikacji do oznaczenia „wyselekcjonowanej jakości" i zatwierdzeniu specyfikacji,

- publikacja decyzji na stronie internetowej ministerstwa rolnictwa.

Kontrola i certyfikacja w systemie: oznaczenia i znaku „wyselekcjonowana jakość” polega na potwierdzeniu zgodności danego produktu rolnego lub środka spożywczego z zatwierdzoną specyfikacją. Stosowny dokument(,certyfikat”), wydawany jest przez organizacje ds. kontroli i certyfikacji. Wyznaczona organizacja ds. kontroli i certyfikacji regularnie powiadamia Ministerstwo i organ odpowiadający za bezpieczeństwo żywności o producentach, przetwórcach produktów rolnych i środków spożywczych oraz ich stowarzyszeniach, którym przyznano certyfikaty lub którym cofnięto certyfikaty.

\section{Systemy jakości w Polsce}

W Polsce obecnie istnieje pięć uznanych przez Ministra Rolnictwa i Rozwoju Wsi krajowych systemów jakości:

- Integrowana Produkcja (IP) Urzędowo Kontrolowana - system mniej restrykcyjny od rolnictwa ekologicznego,

- System „Jakość Tradycja” (JT) - system ochrony i promocji dla produktów tradycyjnych,

- QMP (Quality Meat Program) - system jakości dla mięsa wołowego,

- PQS (Pork Quality System) - system jakości dla mięsa wieprzowego,

- QAFP (Quality Assurance for Food Products) System Gwarantowanej Jakości Żywności QAFP (Minrol, 2017).

Z pośród tych systemów, cztery dotyczą produkcji i produktów zwierzęcych. System „Jakość, Tradycja” obejmuje jednak tylko chów ras tradycyjnych. System, QMP dotyczy tylko mięsa wołowego, PQS chowu świń i produkcji mięsa, natomiast najbardziej kompleksowy charakter ma system QAFP, który obejmuje mięso wieprzowe, mięso drobiowe, wędliny drobiowe i wieprzowo-wołowe. Obecnie trwają prace nad pokryciem systemem rynku miodów, wyrobów mięsnych klasy premium, owoców, warzyw oraz ryb. QAFP może też tworzyć normy dotyczące produkcji i produktów roślinnych, czego obecna „integrowana produkcja” bezpośrednio nie zapewnia.

System QAFP z powodzeniem obejmuje wędliny wieprzowo-wołowe. Mógłby też, by zapewnić ten sam system dla całego sektora, ogarnać całość produkcji wołowiny. 
Obecnie, przy występujących różnicach miedzy zakresami systemów, bezpośrednio można porównać jedynie PQS z QAFP, w jego części dotyczącej wieprzowiny.

Jeśli chodzi o szczegółowe obowiązki producentów żywca wieprzowego to program PQS nie wychodzi poza rozwiązania zaproponowane w programie QAFP. W obu programach:

- wykorzystuje się w krzyżowaniu towarowym wyłącznie świnie ras dostarczających mięso wysokiej jakości kulinarnej z krzyżowania towarowego dwurasowego (wielka biała polska (wbp) x polska biała zwisłoucha (pbz) lub polska biała zwisłoucha (pbz) x wielka biała polska (wbp)) lub trzyrasowego (wielka biała polska (wbp) x polska biała zwisłoucha (pbz) x duroc lub polska biała zwisłoucha (pbz) x wielka biała polska (wbp) $\mathrm{x}$ duroc). W miejsce knurów duroc mogą być używane również knury linii 990,

- wykorzystuje się w krzyżowaniu towarowym wyłącznie świń wolnych od genu RYR1T, czyli genu odpowiedzialnego za zwiększoną częstotliwość występowania wad jakości mięsa typu PSE (od ang. pale - soft - exudative - mięso jasne, miękkie, wodniste),

- przestrzega się podobnych standardów dotyczących żywienia,

- zapewnia się zbliżony poziom mięsności świń (Wymagania, 2013).

Trudno więc stwierdzić dodatkowe korzyści z przynależności do systemu PQS w stosunku do QAFP. Natomiast system QAFP zapewnia dodatkowo, że wszystkie etapy produkcji, od hodowli poprzez ubój, transport, pakowanie i sprzedaż objęte są normami. Wchodząc do systemu użytkownik musi przestrzegać:

- obowiązu zapewnienia zwierzętom odpoczynku w magazynach przed ubojowych po zakończonym transporcie i rozładunku, w warunkach określonych w standardach systemu QAFP,

- określonej w standardach systemu QAFP, górnej granicy czasu, w jakim należy zakończyć czynności uboju i rozpocząć wychładzanie,

- pakowania mięsa kulinarnego objętego znakiem jakości wyłącznie w atmosferze gazów obojętnych (MAP),

- zakazu nastrzykiwania mięsa oraz poddawania go jakimkolwiek innym zabiegom, których celem jest wprowadzenie wody bądź jakichkolwiek substancji dodatkowych,

- zakazu znakowania uprzednio mrożonego mięsa znakiem jakości QAFP (Wymagania, 2013).

To wszystko wpływa na wysoką jakość gotowego produktu. Należy zaznaczyć że System PQS dotyczy tylko produkcji wieprzowiny, natomiast System Gwarantowanej Jakości Żywności (QAFP) ma charakter multiproduktowy, obejmuje mięso wieprzowe, drobiowe oraz wędliny drobiowe $\mathrm{i}$ wieprzowo-wołowe i rozszerza się na inne kierunki produkcji, stąd system ten jest bardziej rozwojowy i przyszłościowy.

Nawet w obrębie samej branży wieprzowiny QAFP jest wygodniejszy w stosowaniu, od innych rozwiązań, tyczy się bowiem norm nie tylko dla chowu trzody, ale i dotyczących produktów gotowych, w tym wędlin, czego nie obejmują inne systemy, także QMP - dla wołowiny.

Należy przypomnieć że system QAFP ma zapewnić:

- Zwiększanie udziału w rynku produktów QAFP

- Wzrost rozpoznawalności znaku QAFP do poziomu $30 \%$

- Rozszerzanie Systemu o nowe grupy asortymentowe w oparciu o nowe zeszyty branżowe 
- Wzrost sprzedaży w całym asortymencie Systemu w oparciu o utrzymanie wysokiej renomy produktów ze znakiem QAFP (Niepublikowane, 2017).

- Zbudowanie narodowego systemu jakości.

System ten jako jedyny zapewnia wypełnianie i przestrzeganie norm jakościowych zarówno w produkcji zwierzęcej, jak i roślinnej. Wzorując się na doświadczeniach francuskich, niemieckich i austriackich, a spośród grupy „nowych” krajów członkowskich UE - słoweńskich, można stwierdzić, że we wszystkich tych krajach jest jeden krajowy system jakości.

W Polsce funkcję tę może $\mathrm{z}$ powodzeniem pełnić, jako najbardziej dojrzały, wykształcony, dynamiczny, obejmujący największa gamę produktów - System Gwarantowanej Jakości Żywności QAFP. Niemniej systemy „Jakość i tradycja” i „Integrowana produkcja” mogłyby nadal funkcjonować.

\section{Podsumowanie}

W krajach Unii Europejskiej, obok wspólnych systemów jakości żywności, występują systemy krajowe (narodowe). W opracowaniu przedstawiono w skrócie rozwiązania zastosowane w Austrii, Niemchech, Francji i Słowenii. Wspólnymi cechami zaprezentowanych systemów zapewnienia jakości żywności jest:

- stworzenie jednego krajowego systemu,

- organem nadzorującym jest albo ministerstwo rolnictwa albo inna agenda rządowa,

- systemy dysponują znakiem o dośc dużej rozpoznawalności i skupiaja znaczną ilość producentów, przetwórców i produktów z różnych branż.

W Polsce narazie systemy działają tylko w szeroko rozumianej branży mięsnej i jest ich pięć. Zapewne wynika to $z$ naszej specyfiki produkcji zwierzęcej i przetwórstwa oraz dużej liczby organizacji branżowych. Zapisane w dokumentach obowiązki producentów i przetwórców nie przesądzają o konieczności istnienia kilku systemów. Najszybciej w Polsce rozwija się system QAFP. Administratorzy wypracowali stategię dalszych działań. Należy więc sądzić, że w niedalekiej przyszłości, może w naszym kraju pozostać jeden, działający w różnych branżach system zapewnienia jakości żywnośći.

\section{Literatura}

Agencja Rynku Rolnego 2013. Systemy jakości żywności - dofinansowanie działań informacyjnych i promocyjnych w ramach PROW. Agencja Rynku Rolnego, Warszawa.

Becker, T., Staus, A. (2008). European food quality policy: the importance of geographical indications, organic certification and food quality insurance schemes in European countries, EAAE Congress, Gent, 26-29 August 2008.

Kieljan, K. (2011). O systemach jakości żywności. Vademecum funkcjonowania produktów regionalnych i tradycyjnych. Centrum Doradztwa Rolniczego w Brwinowie Oddział w Krakowie, Kraków.

Kondraciuk, P., Kubicza, M. (2008). Promocja żywności w krajach UE, Biuletyn Agencji Rynku Rolnego, 9(207), 43-53.

Kowalczyk, S. (2016). Bezpieczeństwo i jakość żywności, PWN Warszawa.

http://www.minrol.gov.pl/pol/ data odczytu: kwiecień.2017.

Niepublikowane materiały Unii Producentów i Pracodawców Przemysłu Mięsnego (2017). Warszawa.

Rozporządzenie Parlamentu Europejskiego i Rady (UE) nr 1151/2012 z dnia 21 listopada 2012 r. w sprawie systemów jakości produktów rolnych i środków spożywczych, Dz. Urzęd. UE L 343 z 14.12.2012. 
Rozporzadzenie Rady (EWG) nr 2081/92 z dnia 14 lipca 1992 r. w sprawie ochrony oznaczeń geograficznych i nazw pochodzenia produktów rolnych i środków spożywczych, Dz. Urzęd. UE L 208 z 24.7.1992.

Rozporządzenie Rady (EWG) nr 2082/92 z dnia 14 lipca 1992 r. w sprawie świadectw o szczególnym charakterze dla produktów rolnych i środków spożywczych, Dz. Urzęd. WE, L 208 z 24.07. 1992.

Rozporządzenie Rady (EWG) 2092/91 z dnia 24 czerwca 1991 r. w sprawie produkcji ekologicznej produktów rolnych oraz znakowania produktów rolnych i środków spożywczych, Dz. Urzęd. L 198 z 22.7.1991.

Rozporządzeniu Komisji (WE) nr 1974/2006 z dnia 15 grudnia 2006 r. ustanawiające szczegółowe zasady stosowania rozporządzenia Rady (WE) nr 1698/2005 w sprawie wsparcia rozwoju obszarów wiejskich przez Europejski Fundusz Rolny na rzecz Rozwoju Obszarów Wiejskich (EFRROW), Dz. Urzęd. $368 \mathrm{z} 23.12 .2006$.

Slovenian Protected Agricultural Products and Foodstuffs (2015). Republic of Slovenia, Ministry of Agriculture, Forestry and Food.

Sprawozdanie z konferencji ministerialnej „Konsumenci maja prawo do informacji” w dniu 19 sierpnia 2016 roku w Mariborze w Słowenii (2016). Materiały ministerstwa Rolnictwa i Rozwoju Wsi.

Wymagania dla systemu QAFP (2013). Część ogólna, Wyd. 4 z dnia 4.12.2013. Pobrane styczeń 2017 z: http://www.qafp.pl/userfiles/files/zeszyty2014/Wymagania\%20dla\%20Systemu\%20QAFP\%20Wyd.\%204\% $20 \mathrm{z} \% 20 \mathrm{dnia} \% 2024.12 .2013$ 